Elsevier

HEARES 01392

\title{
Insulin stimulates protein synthesis and phospholipid signaling systems but does not regulate glucose uptake in the inner ear
}

\author{
Shuchun Wang and Jochen Schacht \\ Kresge Hearing Research Institute, The University of Michigan, Ann Arbor, Michigan, U.S.A.
}

(Received 29 November 1989; accepted 25 February 1990)

\begin{abstract}
High-affinity insulin receptors exist in the organ of Corti $\left(\mathrm{K}_{\mathrm{d}}=1.1 \pm 0.5 \mathrm{nM}\right.$ ) and in the lateral wall (stria vascularis and ligamentum spirale; $\mathrm{K}_{\mathrm{d}}=1.1 \pm 0.4 \mathrm{nM}$ ) of the inner ear of the guinea pig as determined by the binding of radiolabeled porcine or bovine insulin in vitro. Carrier-mediated transport of glucose (defined as the cytochalasin B-sensitive part of total uptake) was measured in vitro with 2-deoxy-D-glucose as the substrate. Its $K_{m}$ was $188 \mu \mathrm{M}$ in the organ of Corti, and $41 \mu \mathrm{M}$ in the lateral wall ( $r=0.99$ and 0.94 , respectively). Neither the $K_{m}$ nor the rates of transport $(0.20 \pm 0.10 \mathrm{pmol} / \mu \mathrm{g}$ protein/hr in the organ of Corti, and $0.56 \pm 0.34 \mathrm{pmol} / \mu \mathrm{g}$ protein $/ \mathrm{hr}$ in the lateral wall) were affected by insulin. In contrast, $0.1 \mathrm{mM}$ ouabain decreased deoxyglucose uptake in the organ of Corti by $37 \%$ and in the lateral wall tissues by $45 \%$ indicating the presence of an active, $\mathrm{Na}^{+}$-dependent transporter in these tissues.

Insulin influenced both protein and lipid metabolism in the inner ear. Proteins and lipids were labeled in situ by perfusion of the perilymphatic space of the cochlea with $\left[{ }^{3} \mathrm{H}\right]$-leucine or $\left[{ }^{32} \mathrm{P}\right]$-orthophosphate and $\left[{ }^{3} \mathrm{H}\right]$-glycerol, respectively. Thirty nM insulin stimulated the incorporation of $\left[{ }^{3} \mathrm{H}\right]$-leucine into protein of the organ of Corti from 39 to $56 \mathrm{pmol} / \mathrm{mg}$ protein but was ineffective in the tissues of the lateral wall. In the organ of Corti, $\left[{ }^{32} \mathrm{P}\right]$-orthophosphate was incorporated into the phosphoinositides and phosphatidate, and $30 \mathrm{nM}$ insulin increased this incorporation by 101 to $149 \%$. With [ $\left.{ }^{3} \mathrm{H}\right]$-glycerol, a trend towards increased incorporation in the presence of insulin was also evident for neutral lipids, phosphatidate, and phosphatidylinositol. In contrast, labeling of phosphatidylcholine (including phosphatidylethanolamine) was reduced. The lateral wall tissues showed a similar pattern of incorporation and a lesser stimulation by insulin. The evidence presented is consistent with a phospholipid-based transmembrane signaling system mediating the effects of insulin on inner ear tissues.
\end{abstract}

Insulin receptors; Glucose uptake; Cochlear metabolism; Second messengers; Diabetes

\section{Introduction}

Insulin, an anabolic polypeptide hormone, has a large number of effects on cellular metabolism and insulin receptors are ubiquitously distributed in the plasma membrane of mammalian cells. Binding of insulin to these receptors initiates a chain of events that leads to tissue-specific biological effects (McGuiness et al., 1987). At the plasma membrane level, insulin may increase the uptake of glucose, stimulate ion flux and activate membrane-bound enzymes such as $\mathrm{Na}^{+} / \mathrm{K}^{+}$-

Correspondence to: Jochen Schacht, Kresge Hearing Research Institute, University of Michigan, Ann Arbor, MI 48109-0506, U.S.A.
ATPase. At the cytoplasmic and mitochondrial level, insulin can regulate cellular metabolism by activating a variety of enzymes such as pyruvate dehydrogenase or glycogen synthase. At the genomic level, insulin can stimulate DNA synthesis and affect the nuclear regulation of specific gene products (Standaert and Pollet, 1988). While intracellular insulin receptors also exist there is growing evidence that plasma membrane actions of the hormone are mediated by phospholipid-derived second messenger systems (Farese and Cooper, 1989).

Although the regulation of glucose uptake and metabolism is generally considered one of the major actions of insulin, not all tissues are subject to this regulation. While muscle and adipose tissue represent typical insulin-sensitive tissues, glucose 
transport, for example, in brush-border membranes of the renal proximal tubule, in brain, and in liver are not under control by this hormone (Baly and Horuk, 1988; Horuk and Olefsky, 1985; Widdas, 1988). Energy metabolism has long been a target of investigations in the auditory and vestibular systems (Thalmann, 1971) but little is known about its regulation and the role that insulin might play. We have previously studied the response of glucose metabolism to acoustic stimulation in the cochlea and the brain stem of the mouse and the gerbil (Canlon and Schacht, 1983; Canlon et al., 1984). In the present study, we investigated basic features of cochlear metabolism by characterizing the insulin receptor and the actions of insulin on glucose transport and protein synthesis. Furthermore, following our interest in the role of phospholipids in the inner ear (Orsulakova et al., 1976; Schacht and Zenner, 1987; Ono and Schacht, 1989) we determined the effects of insulin on phospholipid metabolism in order to investigate the possible involvement of transmembrane signaling systems in the cochlear actions of this hormone.

\section{Materials and Methods}

\section{Insulin binding}

The insulin receptor was assayed by the specific binding of ${ }^{125}$ I-labelled insulin to tissue homogenates (Cuatrecasas, 1971); ${ }^{125}$ I-labelled insulin is a commonly used tracer as its binding charactcristics closely resemble that of native insulin. Guinea pigs were decapitated, their temporal bones removed and dissected in cold Krebs-Ringer bicarbonate buffer $(118 \mathrm{mM} \mathrm{NaCl}, 5 \mathrm{mM} \mathrm{KCl}, 1.2$ $\mathrm{mM} \mathrm{MgSO}_{4}, 25.5 \mathrm{mM} \mathrm{NaHCO}_{3}, 1.2 \mathrm{mM}$ $\mathrm{KH}_{2} \mathrm{PO}_{4}, \mathrm{pH}$ 7.4). Lateral wall tissues (i.e., stria vascularis and spiral ligament) and organ of Corti were collected separately and homogenized in a glass/glass homogenizer. The homogenate was incubated for $1 \mathrm{~h}$ at $25^{\circ} \mathrm{C}$ in a millititer filter well (Millipore Corp., Bedford, MA) in $100 \mu$ l of Krebs buffer with $1 \%$ bovine serum albumin and $44 \mathrm{nCi}$ of ${ }^{125}$ I-labelled insulin (porcine receptor grade, $2200 \mathrm{Ci} / \mathrm{mm} u l$, New England Nuclear, Boston, MA) and varying concentrations (100 pM to 100 $\mathrm{nM}$ ) of unlabeled insulin (Sigma, St. Louis, MO). At the end of the incubation the homogenate was filtered under reduced pressure, washed with cold buffer, and radioactivity on the filter was counted in a gamma-counter. Non-specific binding was determined in parallel in all experiments as radioactivity in the presence of $2 \mu \mathrm{M}$ of unlabeled insulin; specific binding was obtained by subtracting this value from total binding. The protein content in the well was determined with the Bradford protein assay (Bio RAD, Richmond, CA).

\section{Glucose uptake}

Sections of the organ of Corti and lateral wall tissues ( $1 / 4$ to $1 / 2$ of the cochlear content of each tissue corresponding to 5 to $20 \mu \mathrm{g}$ protein for organ of Corti, and 20 to $35 \mu \mathrm{g}$ for the lateral wall) were pre-incubated for $10 \mathrm{~min}$ at $37^{\circ} \mathrm{C}$ in 50 $\mu l$ of Krebs-Ringer bicarbonate buffer with $1 \%$ bovine serum albumin and varying concentrations of unlabeled deoxyglucose in the absence and presence of insulin (Kuroda et al., 1987). After the pre-incubation, $50 \mu 1$ of $2-\left[1,2-{ }^{3} \mathrm{H}\right]$ deoxy-D-glucose $(900 \mathrm{nCi}, 20 \mathrm{pmol}$; American Radiolabeled Chemicals Inc., St. Louis, MO) were added and the incubation continued for $30 \mathrm{~min}$. The uptake was terminated by placing the tube in an ice bath and adding $600 \mu \mathrm{l}$ of cold buffer. After centrifugation at $12,000 \times g$ for 3 min the supernatant was aspirated and the pellet quickly washed with 700 $\mu \mathrm{l}$ of cold buffer. The pellet was solubilized in 10 $\mu \mathrm{l}$ of $1 \mathrm{~N} \mathrm{NaOH}$ and subsequently $90 \mu \mathrm{l}$ of $\mathrm{H}_{2} \mathrm{O}$ were added. Forty-five $\mu 1$ each were taken to count radioactivity and to quantify protein. Nontransport mediated deoxyglucose uptake was determined in the presence of $60 \mu \mathrm{M}$ cytochalasin $\mathrm{B}$. The transport-mediated uptake of deoxyglucose was defined as the difference between total uptake and that in the presence of cytochalasin B.

Perilymphatic perfusions were performed on guinea pigs $(200-300 \mathrm{~g})$ displaying a positive Preyer hearing reflex. The procedure was essentially as described by Bohbin and Konishi (1974) and Nuttall et al. (1982). Animals were anesthetized with $20 \mathrm{mg}$ sodium pentobarbital $/ \mathrm{kg}$ bodyweight injected intraperitoneally and $0.5 \mathrm{ml}$ Innovar $(0.2$ $\mathrm{mg}$ fentanyl and $10 \mathrm{mg}$ droperidol) $/ \mathrm{kg}$ injected intramuscularly. Artificial respiration was provided through a tracheal cannula and body temperature was maintained at $37^{\circ} \mathrm{C}$ with a heating pad. The left auditory bulla was opened via a 
standard ventral approach and the cochlea was exposed. The cochlear microphonic potential (CM) was recorded from the round window by a wire electrode prior to and during the perfusion. Two holes were drilled in the cochlea: the first was located in the scala tympani of the basal turn and the second in the scala vestibuli of the apical turn. A glass capillary inserted into the first hole was connected to a peristaltic pump via plastic tubing. A degassed solution of artificial perilymph (130 $\mathrm{mM} \mathrm{NaCl}, 1 \mathrm{mM} \mathrm{CaCl}{ }_{2}, 2 \mathrm{mM} \mathrm{MgCl}_{2}, 8.2 \mathrm{mM}$ $\mathrm{KCl}, 10 \mathrm{mM} \mathrm{NaHCO}, 5 \mathrm{mM}$ glucose, $0.1 \mathrm{mM}$ $\mathrm{NaH}_{2} \mathrm{PO}_{4}$, and $10 \mathrm{mM}$ HEPES (N-2-hydroxyethylpiperazine $\mathrm{N}^{\prime}$-2-ethanesulfonic acid), $\mathrm{pH}$ 7.4), with or without $30 \mathrm{nM}$ bovine or porcine insulin, as indicated, was pre-filled into the capillary and perfused from base to apex. The perfusion was terminated by an injection of $0.4 \mathrm{ml}$ of $2 \%$ glutaraldehyde plus $4 \%$ formaldehyde into the cochlea via the round window. The temporal bone was removed and kept in glutaraldehyde/formaldehyde solution until tissues were dissected.

\section{Protein synthesis}

${ }^{3} \mathrm{H}$-leucine $\left(100 \mu \mathrm{Ci} / \mathrm{ml}\left[2.3 .4 .5-{ }^{3} \mathrm{H}\right]\right.$-leucine, ICN Radiochemicals, Irvine, CA) was added to the perfusate as the radioactive precursor for $1 \mathrm{~h}$ following a $15 \mathrm{~min}$ perfusion without radioactivity. After fixation and dissection as described above, the tissues were homogenized in $300 \mu \mathrm{l}$ of $10 \%$ aqueous trichloroacetic acid (TCA) and the homogenate was centrifuged at $12,000 \times g$ for 1 min. The precipitate was washed twice with $10 \%$ TCA and once with ether and then solubilized in $20 \mu \mathrm{l}$ of $5 \mathrm{~N} \mathrm{NaOH}$ by heating in a boiling water bath for several minutes. Four hundred $\mu \mathrm{l}$ of 0.25 $\mathrm{N}$ acetic acid were added; $200 \mu \mathrm{l}$ of the solution was taken for counting radioactivity and $100 \mu \mathrm{l}$ for measuring protein. The amount of ${ }^{3} \mathrm{H}$-leucine incorporated into protein was expressed per $\mu \mathrm{g}$ tissue protein.

\section{Phospholipid labeling}

For radioactive labeling of lipids, $\left[{ }^{32} \mathrm{P}\right]$-orthophosphate (30-50 $\mu \mathrm{Ci} / \mathrm{ml}$; ICN Radiochemicals, Irvine, CA) or ${ }^{3} \mathrm{H}$-glycerol $(200 \mu \mathrm{Ci} / \mathrm{ml}$; [1.2.3$\left.{ }^{3} \mathrm{H}\right]$-glycerol, New England Nuclear, Boston, MA) was added to the perfusion fluid for $90 \mathrm{~min}$. The phospholipids were extracted, separated by thin layer chromatography and their radioactivity determined as described previously (Orsulakova et al., 1976).

\section{Results}

\section{Insulin receptors}

Insulin receptors could be demonstrated in the lateral wall tissues and the organ of Corti (Table I) and their kinetic parameters were essentially similar for both tissues. The dissociation constants in the low nanomolar range indicated the presence of a high affinity receptor and the binding capacity in these crude homogenates was also similar for both tissues. A low affinity binding site became apparent at higher insulin concentrations in the assay but its parameters were not quantified.

\section{Deoxyglucose transport}

The total uptake of deoxy-D-glucose increased with time for $1 \mathrm{~h}$ in the lateral wall tissues and for $30 \mathrm{~min}$ in the organ of Corti (Fig. 1). The fraction of non-transport-mediated uptake determined in the presence of cytochalasin B showed a similar linearity with time and comprised between 20 and $70 \%$ of the total uptake depending on the tissue and time of incubation. The active component of the transport had a somewhat higher affinity for glucose and a somewhat smaller $V_{\max }$ in the lateral wall tissues than in the organ of Corti (Table II).

The effect of insulin and ouabain on deoxyglucose transport

The effect of insulin was determined at a deoxyglucose concentration of $100 \mu \mathrm{M}$. At this con-

\section{TABLE I}

DISSOCIATION CONSTANTS $\left(K_{\mathrm{d}}\right)$ AND BINDING CAPACITY $\left(B_{\max }\right)$ OF INSULIN RECEPTORS IN INNER EAR TISSUES

\begin{tabular}{lll}
\hline Tissue & $\begin{array}{l}K_{\mathrm{d}} \\
(\mathrm{nM})\end{array}$ & $\begin{array}{l}\mathrm{B}_{\max } \\
(\mathrm{nmol} / \mu \mathrm{g} \text { protein })\end{array}$ \\
\hline Organ of Corti & $1.1 \pm 0.5$ & $8.2 \pm 4.7$ \\
Lateral wall & $1.1 \pm 0.4$ & $4.3 \pm 1.3$ \\
\hline
\end{tabular}

The assay of ${ }^{125} \mathrm{I}$-insulin binding was performed as described in 'Methods'. $K_{\mathrm{d}}$ and $\mathbf{B}_{\max }$ were calculated from a Scatchard analysis and values are means $\pm S D$ of four independent experiments except $\mathrm{B}_{\max }$ in the organ of Corti (two experiments; means and range). 


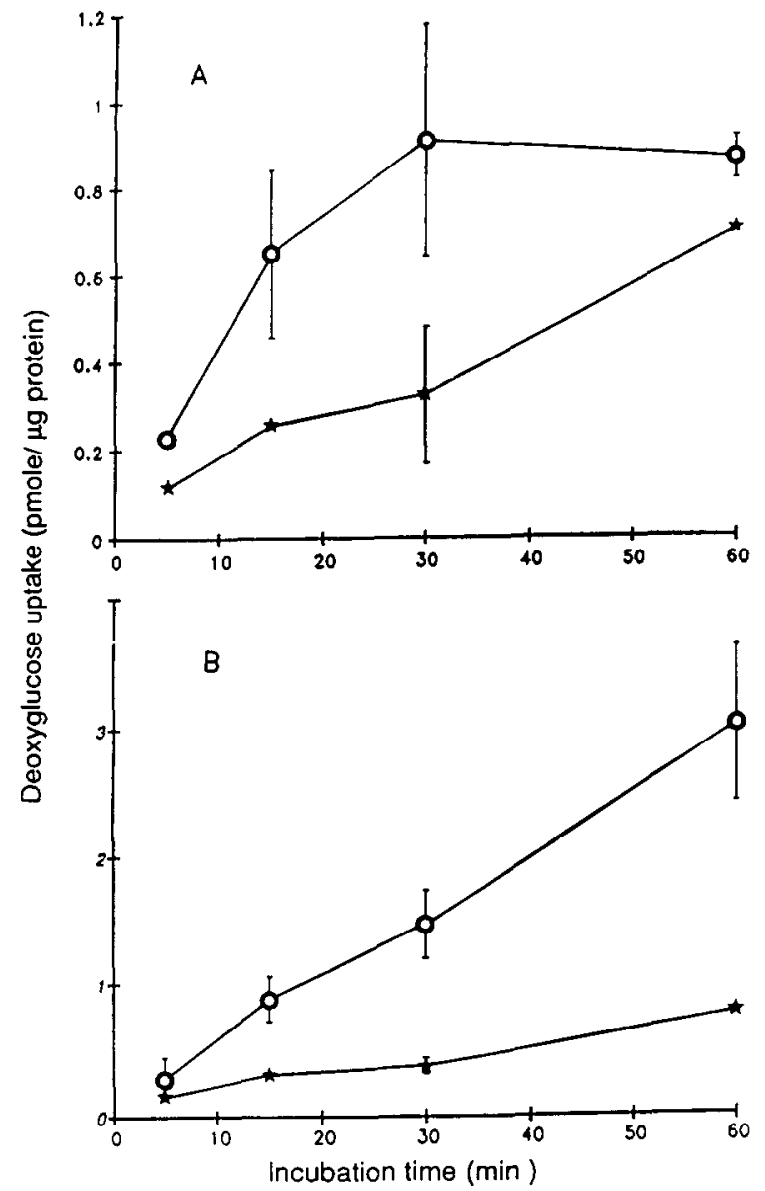

Fig. 1. Time course of deoxy-D-glucose uptake. A. Organ of Corti; B. Lateral wall tissues. Tissues were incubated with ${ }^{3} \mathrm{H}$-deoxy-D-glucose $(900 \mathrm{nCi}, 200 \mathrm{pmol} / \mathrm{ml})$ for the times indicated as described in 'Methods'. $O=$ total uptake; * = uptake in the presence of $60 \mu \mathrm{M}$ cytochalasin B. Each point represents the mean \pm SD of three determinations in two independent experiments except values for the cytochalasin B experiments at 5, 15, and $60 \mathrm{~min}$ which are from single determinations.

centration, the rate of active transport was essentially unaffected in both the lateral wall tissues and the organ of Corti by 10 to $100 \mathrm{nM}$ insulin (Table III), concentrations sufficient to stimulate glucose uptake maximally in other tissues (Draznin et al., 1988).

In contrast to insulin, the $\mathrm{Na}^{+} / \mathrm{K}^{+}$-ATPase inhibitor ouabain affected deoxyglucose uptake in both the organ of Corti and lateral wall tissues. Deoxyglucose uptake in the presence of $0.1 \mathrm{mM}$ ouabain was decreased by $37 \%$ in the organ of
TABLE II

MICHAELIS-MENTEN CONSTANTS $\left(K_{m}\right)$ and $V_{\text {max }}$ of DEOXY-D-GLUCOSE TRANSPORT

\begin{tabular}{lrll}
\hline Tissue & $\begin{array}{l}K_{\mathrm{m}} \\
(\mu \mathrm{M})\end{array}$ & $\begin{array}{l}V_{\max } \\
(\mathrm{pmol} / \mu \mathrm{g} \\
\text { protein } / \mathrm{h})\end{array}$ & $r$ \\
\hline Organ of Corti & 188.4 & 1.70 & 0.99 \\
Lateral wall & 40.8 & 0.64 & 0.94 \\
\hline
\end{tabular}

Tissues were incubated in Krebs-Ringer bicarbonate buffer with ${ }^{3} \mathrm{H}$-deoxy-D-glucose $(900 \mathrm{nCi})$ and specific transport was calculated as described in 'Methods'. $K_{m}$ and $V_{\max }$ were determined from Lineweaver-Burk analysis of four experiments with deoxyglucose concentrations ranging from 0.01 to 1 mM. $r$, correlation coefficient.

Corti and by $44 \%$ in the lateral wall tissues (Table III).

Additionally, glucose transport was assessed in animals that had been food-deprived for $24 \mathrm{~h}$. Blood glucose concentration dropped significantly from $2.0 \pm 0.6 \mathrm{mg} / \mathrm{ml}$ in guinea pigs fed ad libitum to $1.4 \pm 0.1 \mathrm{mg} / \mathrm{ml}(P<0.05)$. Deoxyglucose transport in the organ of Corti of food-deprived guinea pigs, however, remained essentially unchanged (Fig. 2A) and transport in the lateral wall increased only at higher glucose concentrations (Fig. 2B).

TABLE III

THE EFFECT OF INSULIN AND OUABAIN ON DEOXYGLUCOSE TRANSPORT

\begin{tabular}{|c|c|c|}
\hline & $\begin{array}{l}\text { deoxy-1)-glucos } \\
\text { (pmol/ } \mu \mathrm{g} \text { prote }\end{array}$ & $\begin{array}{l}\text { nsport } \\
\text { h) }\end{array}$ \\
\hline & Organ of Corti & Lateral Wall \\
\hline Experiment 1: & & \\
\hline Control & $0.20 \pm 0.10$ & $0.56 \pm 0.34$ \\
\hline $10 \mathrm{nM}$ insulin & $0.18 \pm 0.12$ & $0.56 \pm 0.34$ \\
\hline $100 \mathrm{nM}$ insulin & $0.18 \pm 0.06$ & $0.50 \pm 0.26$ \\
\hline Experiment 2: & & \\
\hline Control & $0.92 \pm 0.34$ & $1.26 \pm 0.28$ \\
\hline $100 \mu \mathrm{M}$ nuahain & $0.58 \pm 0.18 *$ & $0.70 \pm 0.14 * *$ \\
\hline
\end{tabular}

Tissues were incubated with $0.1 \mathrm{mM}^{3} H$-deoxy-D-glucose in the absence and presence of insulin or nuabain as described in 'Methods'. 'Glucose transport' represents specific (cytochalasin-sensitive) uptake in experiment 1. and total uptake in experiment 2 . Values are means \pm SD of six to cight determinations. ${ }^{*} 0.04<P<0.05 ;{ }^{* *} P<0.005$. 
The effect of insulin on protein synthesis

Insulin stimulated the incorporation of ${ }^{3} \mathrm{H}$ leucine into proteins in the organ of Corti but not the lateral wall (Table IV). In the organ of Corti the rate of incorporation increased by $45 \%$ in the presence of $30 \mathrm{nM}$ bovine insulin $(P<0.06)$ while the effect in the lateral wall tissues was not significant. A parallel set of experiments with porcine insulin showed essentially the same trend: incorporation into the organ of Corti was elevated (although somewhat less than by bovine insulin) to $45.6 \pm 19.7 \mathrm{fmol} / \mu \mathrm{g}$ protein, while incorpora-

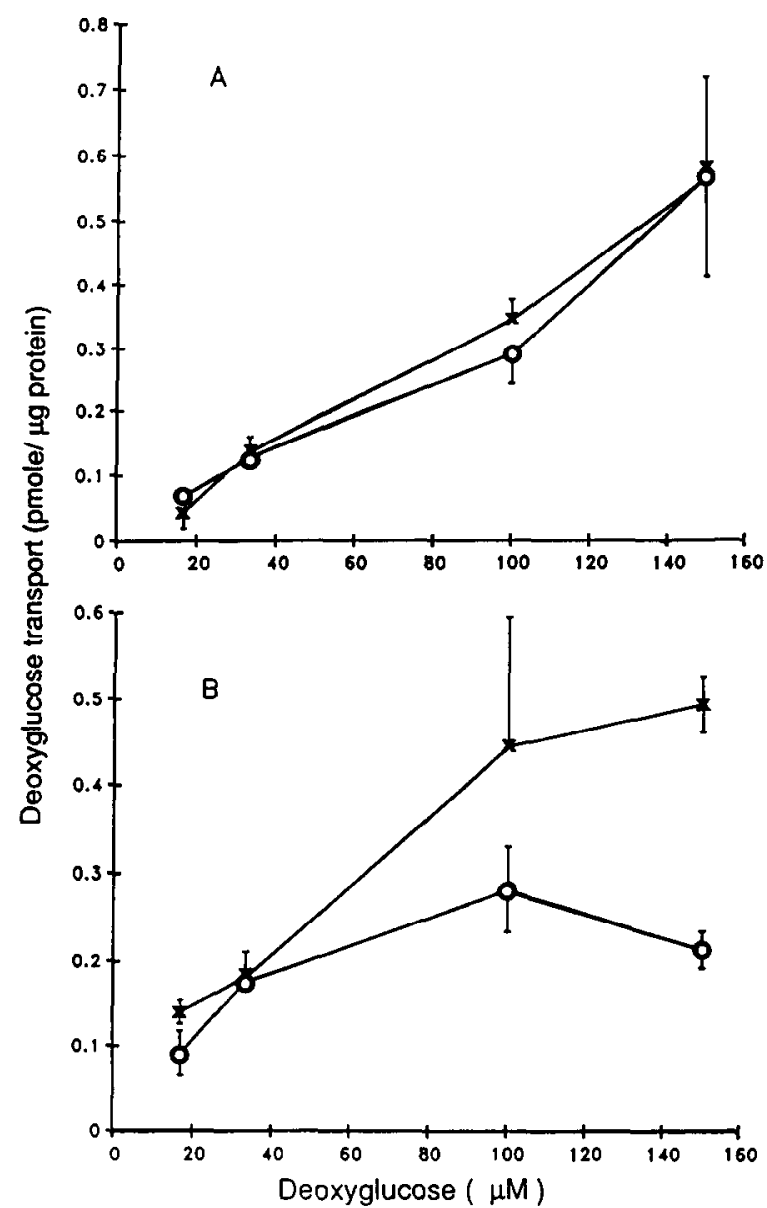

Fig. 2. Effect of food-deprivation on deoxyglucose transport.(A) Organ of Corti; (B) Lateral wall tissues.Guinea pigs were food-deprived for $24 \mathrm{~h}$. Glucose transport was mcasured as described in 'Methods'. Values are the means \pm SD of three to four experiments. Rate of transport is significantly different in food-deprived animals in the lateral wall at $150 \mu \mathrm{M}$ deoxyglucose $(P=0.035) . O=$ normal animals; $\times$ food deprived.
TABLE IV

THE EFFECT OF INSULIN ON ${ }^{3} I I$-LEUCINE INCORPORATION INTO PROTEIN

\begin{tabular}{llll}
\hline & \multicolumn{3}{c}{$H$-leucine incorporated $(\mathrm{fmol} / \mu \mathrm{g}$ protein) } \\
\cline { 2 - 4 } & Organ of Corti & Lateral Wall & Ratio \\
\hline Control & $38.6 \pm 13.9$ & $49.2 \pm 22.5$ & $0.97 \pm 0.12$ \\
Insulin & $55.8 \pm 20.7 *$ & $39.0 \pm 15.4$ & $1.49 \pm 0.32 * *$ \\
\hline
\end{tabular}

Perilymphatic perfusions were performed with $\left[{ }^{3} H\right]$-leucine $(100 \mu \mathrm{Ci} / \mathrm{ml})$ in the absence or presence of $30 \mathrm{nM}$ bovine insulin as described in 'Methods'. Values are means \pm SD of six experiments. 'Ratio' indicates the means $\pm \mathrm{SD}$ of the ratios of labeled ${ }^{3} \mathrm{H}$-leucine in the organ of Corti to that in lateral wall as calculated from individual experiments. ${ }^{*} 0.05<P<0.06$; ** $P<0.01$.

tion in the lateral wall tissues $(39.5 \pm 6.6 \mathrm{fmol} / \mu \mathrm{g}$ protein) was practically identical to that in the presence of bovine insulin. The differential effect of insulin on protein synthesis in the two tissues was even more clearly evident when the ratio of $\left[{ }^{3} \mathrm{H}\right]$-leucine incorporation in the organ of Corti was compared to that in the lateral wall tissue of the same animals. This ratio increased significantly by $50 \%$ in the presence of insulin $(P<0.01$; Table IV).

\section{The effect of insulin on labeling of phospholipids}

Following perilymphatic perfusions with $\left[{ }^{32} \mathrm{P}\right]-$ orthophosphate the polyphosphoinositides, phosphatidylinositol 4-phosphate and phosphatidylinositol 4,5-bisphosphate, were the most highly labeled lipids in both tissues (Table V). They comprised $78 \%$ and $64 \%$ of the total labeled lipids in the organ of Corti and the lateral wall tissues, respectively. Phosphatidic acid and phosphatidylinositol were the only other lipids incorporating a significant amount of $\mathrm{P}_{\mathrm{i}}$. With ${ }^{3} \mathrm{H}$-glycerol as precursor, neutral lipids (comprising di- and triglycerides), phosphatidylinositol, phosphatidylcholine and phosphatidylethanolamine (determined together), and phosphatidate were the major labeled products (Table VI) while the polyphosphoinositides did not contain appreciable amounts of radioactivity. These results on lipid labeling are in good agreement with earlier studies (Stockhorst and Schacht, 1977; Tachibana et al., 1983). 
TABLE V

THE EFFECT OF INSULIN ON ${ }^{[32]} P_{\mathrm{i}}$ INCORPORATION INTO PHOSPHOLIPIDS

\begin{tabular}{|c|c|c|c|c|}
\hline \multicolumn{5}{|c|}{$P_{i}$ incorporated (pmol $/ \mathrm{mg}$ protein) } \\
\hline \multicolumn{5}{|c|}{ a) Organ of Corti } \\
\hline & PtdInsP2 & PtdInsP & PtdIns & Ptd \\
\hline Control & $0.46 \pm 0.34$ & $0.32 \pm 0.24$ & $0.31 \pm 0.23$ & $0.15 \pm 0.10$ \\
\hline+ insulin & $0.92 \pm 0.56^{*}$ & $0.80 \pm 0.52 * *$ & $0.66 \pm 0.23 * *$ & $0.36 \pm 0.21 * *$ \\
\hline$\%$ increase & 101 & 149 & 117 & 142 \\
\hline \multicolumn{5}{|c|}{ b) Lateral Wall } \\
\hline & PtdInsP2 & PtdInsP & PtdIns & Ptd \\
\hline Control & $0.39 \pm 0.22$ & $0.25 \pm 0.19$ & $0.13 \pm 0.09$ & $0.07 \pm 0.05$ \\
\hline+ insulin & $0.71 \pm 0.49$ & $0.37 \pm 0.31$ & $0.20 \pm 0.12$ & $0.11 \pm 0.08 * *$ \\
\hline$\%$ increase & 83 & $52-$ & 56 & 66 \\
\hline
\end{tabular}

Perilymphatic perfusions were performed with ${ }^{32} \mathrm{P}_{\mathrm{i}}(50 \mu \mathrm{Ci} / \mathrm{ml})$ in the absence or presence of 30 nM bovine insulin. Values are the means $\pm \mathrm{SD}$ of five experiments. Abbreviations: Ptd $=$ phosphatidic acid; PtdIns $=$ phosphatidyl-inositol; PtdlnsP $=$ phosphatidylinositol 4-phosphate; PtdInsP2 $=$ phosphatidylinositol 4,5-biphosphate. ${ }^{*} P=0.08 ; * * 0.02<P<0.05$.

The presence of $30 \mathrm{nM}$ bovine insulin in the perfusate significantly increased $\mathrm{P}_{\mathrm{i}}$-incorporation into phospholipids in the organ of Corti by $101 \%$ to $149 \%$ and a similar trend was observed in the lateral wall tissues with increases ranging from $52 \%$ to $83 \%$ (Table V). Labeling from ${ }^{3} \mathrm{H}$-glycerol also tended to increase in all lipids in the presence of insulin with the exception of the phosphatidylcholine fraction in which insulin actually in- duced a loss of labeling in the organ of Corti (Table VI).

\section{Discussion}

The salient finding of this study is that insulin does not regulate glucose uptake in the organ of Corti and the tissues of the lateral wall of the

TABLE VI

THE EFFECT OF INSULIN ON ${ }^{3}$ H-GLYCEROL INCORPORATION INTO LIPIDS

\begin{tabular}{|c|c|c|c|c|}
\hline & \multicolumn{4}{|c|}{ Glycerol incorporated (fmol/mg protein) } \\
\hline \multicolumn{5}{|c|}{ a) Organ of Corti } \\
\hline & NL & Ptd & PtdCho+PtdEth & PtdIns \\
\hline Control & $14.8 \pm 10.4$ & $2.57 \pm 1.82$ & $7.87 \pm 4.24$ & $9.76 \pm 6.49$ \\
\hline+ insulin & $22.7 \pm 16.0$ & $4.63 \pm 4.68$ & $6.23 \pm 3.82$ & $17.5 \pm 9.80$ \\
\hline$\%$ increase & 53 & 80 & -21 & 80 \\
\hline \multicolumn{5}{|c|}{ b) Lateral Wall } \\
\hline & NL & Ptd & PtdCho + PtdEth & PtdIns \\
\hline Control & $5.89 \pm 3.68$ & $0.98 \pm 0.59$ & $2.08 \pm 1.12$ & $3.73 \pm 2.93$ \\
\hline+ insulin & $9.00 \pm 7.73$ & $1.65 \pm 1.39$ & $2.38 \pm 1.56$ & $4.99 \pm 3.44$ \\
\hline$\%$ increase & 53 & 69 & 14 & 34 \\
\hline
\end{tabular}

Perilymphatic perfusions were performed with ${ }^{3} \mathrm{H}$-glycerol $(200 \mu \mathrm{Ci} / \mathrm{ml})$ as described in 'Methods'. Values are means $\pm \mathrm{SD}$ of five experiments. Abbreviations: NL $=$ neutral lipids; PtdCho $=$ phosphatidylcholine; PtdEth $=$ phosphatidylethanolamine; for others see Table 5. 
guinea pig. It influences, however, protein and phospholipid metabolism in these tissues.

The insulin receptors in the inner ear appear similar in their ability to bind insulin, and the observed $\mathrm{K}_{\mathrm{d}}$ of $1.1 \mathrm{nM}$ is of the same magnitude as measured for insulin receptors in other tissues, e.g. $1.9 \mathrm{nM}$ in human adipocytes (Olefsky et al., 1974). In contrast, the kinetics of glucose uptake differ between lateral wall tissues and the organ of Corti with the latter showing a four-fold higher $\mathrm{K}_{\mathrm{m}}$ for glucose. Both $\mathrm{K}_{\mathrm{m}}$ are considerably lower than those reported for brain $(9 \mathrm{mM})$, kidney (5 $\mathrm{mM}$ ) or other tissues where values usually are in the low millimolar range (Baly and Horuk, 1988). This can be interpreted as an ability of the inner ear tissues to saturate their transport systems already at glucose concentrations lower than normally found in serum or perilymph.

One problem associated with measuring the transport rate of glucose is the fact that subsequent metabolism of glucose may affect the observed rate. This influence can be minimized with the use of non-metabolized analogs of glucose which more specifically reflect uptake. 2-Deoxyglucose for which we report data here and 3-O-methylglucose are such widely used analogues. While 2-deoxyglucose is still a substrate for hexokinase, 3-O-methylglucose is not. However, in a preliminary series of experiments with $\left[{ }^{3} \mathrm{H}\right]-3-\mathrm{O}-m e t h y l g l u c o s e$ (data not shown) we obtained similar values for glucose transport in the lateral wall tissues.

In animal tissues glucose is transported by a variety of mechanisms depending on the type of cell. Both active (energy-dependent) and passive (driven only by the glucose gradient) transport systems have been characterized, sometimes both in the same type of cell. Cytochalasin B distinguishes a specific carrier-mediated transport (facilitated diffusion) from a simple diffusion process by inhibiting the glucose carrier. Such cytochalasin-sensitive transport is present in the inner ear tissues. The reduction of glucose uptake by the $\mathrm{Na}^{+} / \mathrm{K}^{+}$-ATPase inhibitor ouabain additionally indicates that the glucose transporter in the inner ear tissues is also at least partially an active, $\mathrm{Na}^{+}$-dependent transporter. This means that inner ear tissues can perform an "uphill" transport of glucose against a concentration gradient, i.e. they are capable of extracting glucose from the surrounding fluids.

Carrier-mediated glucose uptake seems to exhibit at least two distinct forms. These can be distinguished by their response to glucose-deprivation which has been shown to lead to cell-specific alterations of glucose transport in vivo and in tissue culture. Hypoglycemic conditions significantly increase the number of glucose-transporters in adipocytes and brain tissues in vivo as well as in rat brain glial cultures in vitro. In contrast, rat brain neuronal cultures showed only a small change in glucose transport (Walker et al., 1988). Organ of Corti and lateral wall appear to differ in their response to glucose-deprivation: there is no effect on transport in the organ of Corti but a significant increase in stria vascularis. It is thus interesting to speculate about a "neuronal-type" transport in the organ of Corti and a "glial-type" transport in the lateral wall tissues.

In several body tissues glucose transport across the plasma membrane is under acute control of insulin which increases the transport rate $\left(V_{\max }\right)$ presumably by increasing the number of functional transporter molecules. Neither glucose uptake in the organ of Corti nor in the tissues of the lateral wall is responsive to insulin. A lack of hormonal regulation implies that glucose transport in the inner ear tissues is not a rate-limiting process in energy metabolism.

For a consideration of diabetes mellitus, our results suggest that glucose metabolism in the inner ear is not a direct target of an insulin deficiency. This appears consistent with the fact that pathology in general and metabolic disturbances in particular are subtle if at all present in the inner ear in the diabetic state (Horoupian, 1988; Morrison and Booth, 1988). Other primary metabolic targets seem therefore more likely if indeed a causal relationship exists between diabetes and hearing disorders.

In contrast to its lack of effect on glucose transport, insulin increases the turnover of proteins and lipids in the inner ear. The hormone-enhanced protein synthesis as measured by the incorporation of a radiolabelled amino acid may reflect an increase of the metabolic rate of the tissue since the induction of synthesis of specific proteins should require a longer time course of 
insulin action. Such activation of anabolic processes is one of the well-documented actions of insulin. Acute effects on protein synthesis may occur through regulation of peptide-chain initiation although other steps in protein synthesis may also be the target (Kimball and Jefferson, 1988; Miller 1988). This response to insulin was observed in the organ of Corti but not in the lateral wall. Consistent with the results of the glucose-deprivation experiment and the lipid labelling, this finding points to differential effects of the hormone on the organ of Corti and the tissues of the lateral wall.

Both organ of Corti and the lateral wall tissues show the metabolic response of phospholipid metabolisin to insulin albeit the latter to a lesser extent. Radioactive labeling of phospholipids can be increased either by de-novo synthesis or by accelerating their hydrolysis and thus their turnover (Friedman et al., 1985; Farese et al., 1986; Augert and Exton 1988). While an activation of de-novo metabolism may be a reflection of an increased metabolic rate of the tissue, the latter type of action would imply phospholipids in the transmembrane signaling process for this hormone presumably through an activation of phospholipase $C$. The fact that the incorporation not only of ${ }^{32} \mathrm{P}_{\mathrm{i}}$ but also of ${ }^{3} \mathrm{H}$-glycerol into most lipids shows a trend towards stimulation indicates a contribution of de-novo synthesis to the observed lipid labeling effect. This result also argues against the possibility that the increase in ${ }^{32}$ P-lipids is simply a consequence of an increase in the specific radioactivity of the precursor, $\left[\gamma_{-}{ }^{32} \mathrm{P}\right] \mathrm{ATP}$.

It is interesting to consider that insulin receptors in the inner ear may be coupled to transmembrane signaling systems. In the case of insulin action, a phosphatidylinositol-glycan has been suggested as a substrate of a phospholipase C (Romero et al., 1988) but this specific possibility was not investigated in our study. A very similar response of ${ }^{32} \mathrm{P}_{\mathrm{i}}$-incorporation to insulin as the one described here has been observed in rat epididymal fat pads (Farese et al., 1986) where the hormone activates phospholipid-based second messenger systems. In addition, the stimulation of de-novo synthesis of phosphatidic acid has been reported as part of a triad of insulin actions on phospholipid metabolism which additionally in- cludes the increased hydrolysis of phosphatidylcholine (Farese et al., 1984; Farese, 1988). It is intriguing that we observe both an increased synthesis of phosphatidic acid and a reduction of glycerol incorporation into phosphatidylcholine with insulin in the organ of Corti. The effect is less conspicuous in the lateral wall tissues altough the trend is similar. The combined evidence is thus consistent with the interpretation that a phospholipid-based transmembrane signaling system mediates the effects of insulin on inner ear tissues.

\section{Acknowledgment}

This research was supported by NIH Program Project grant NS-05785. The authors also wish to thank the Michigan Diabetes Center for analytical help in this study.

\section{References}

Augert, G. and Exton, J.H. (1988) Insulin and oxytocin effects on phosphoinositide metabolism in adipocytes. J. Biol. Chem. 263, 3600-3609.

Baly, D.L. and Horuk, R. (1988) The biology and biochemistry of the glucose transporter. Biochim. Biophys. Acta 947. 571590 .

Bobbin, R.P. and Konishi, T. (1974) Action of cholinergic and anticholinergic drugs at the crossed olivocochlear bundlehair cell junction. Acta Otolaryngol. 77, 56-65.

Canlon, B. and Schacht, J. (1983) Acoustic stimulation alters deoxyglucose uptake in the mouse cochlea and inferior colliculus. Hear. Res. 10, 217-226.

Canlon,B.. Takada.A., and Schacht.J. (1984) Glucose utilization in the auditory system. Cochlear dysfunctions and species differences. Comp. Biochem. Physiol. 78A, 43-47.

Cuatrecasas, P. (1971) Insulin receptor interaction in adipose tissue cells, Direct measurement and properties. Proc. Nat. Acad. Sci. USA 68, 1264-1268.

Draznin, B., Sussman, K.E.. Kuo, M. and Sherman,N. (1988) Relationship between cytosolic free calcium concentration and 2-deoxyglucose uptake in adipocytes isolated from 2-and 12 month old rats. Endocrinology 122, 2578-2583.

Farese, R.V. (1988) Phospholipid signaling systems in insulin action. Am. J. Med. 85 (Suppl. 5A). 36-43.

Farese, R.V., Barnes, D.E., Davis, J.S., Standaert, M.L. and Pollet.R.J. (1984) Effects of insulin and protein synthesis inhibitors on phospholipid metabolism, diacylglycerol levels, and pyruvate dehydrogenase activity in $\mathrm{BC} 3 \mathrm{H}-1$ cultured myocytes. J. Biol. Chem. 259, 7094-7100.

Farese, R. V., Kuo, J.Y., Babischkin, J.S. and Davis, J.S. (1986) Insulin provokes a transient activation of phospholipase $C$ in the rat epididymal fat pad. J. Biol. Chem. 261. 8589-8592. 
Farese, R.V. and Cooper, D.R. (1989) Potential role of phospholipid-signaling systems in insulin action and states of clinical insulin resistance. Diabet. Metab. Rev. 5, 455-474.

Friedman, Y., Poleck, J., Henricks, L. and Burke, G. (1985) Diacylglycerol-activated calcium/phospholipid-dependent protein kinase (protein kinase C) activity in bovine thyroid. Biochem. Biophys. Res. Comm. 130, 971-980.

Horoupian, D. (1988) Pathology of the central auditory pathways and cochlear nerve. In: P. W. Alberti and R.J. Ruben (Eds.), Otologic Medicine and Surgery, Churchill Livingstone, New York, pp. 713-734.

Horuk, R. and Olefsky, J.M. (1985) Post binding events in insulin action. Diabet. Metab. Rev. 1, 59-97.

Kimball, S.R. and Jefferson, L.S. (1988) Cellular mechanisms involved in the action of insulin on protein synthesis. Diabet. Metab. Rev. 4, 773-787.

Kuroda, M., Honnor, R.C., Cushman, S.W., Londos, C. and Simpson, I.A. (1987) Regulation of insulin-stimulated glucose transport in the isolated rat adipocyte. J. Biol. Chem. $262,245-253$.

Miller, D.S. (1988) Stimulation of RNA and protein synthesis by intracellular insulin. Science 240, 506-508.

McGuiness, O.P., Steiner, K.E., Abumrad, N.N. and Cherrington, A.D. (1987) Insulin action in vivo. In: K.G.M.M. Alberti and L.P. Krall (Eds.), The Diabetes Annual, Elsevier, Amsterdam, vol 3, pp. 398-432.

Morrison, A.W. and Booth, J.B. (1988) Systemic disease and otology. In: P. W. Alberti and R.J. Ruben (Eds), Otologic Medicine and Surgery, Churchill Livingstone, New York, pp. 855-883.

Nuttall, A.L., LaRouere, M.J. and Lawrence, M. (1982) Acute perilymphatic perfusion of the guinea pig cochlea. Hear. Res. 6, 207-221.

Olefsky, J.M., Jen, P. and Reaven, G.M. (1974) Insulin binding to isolated human adipocytes. Diabetes $23,565-571$.
Ono, T. and Schacht, J. (1989) Acoustic stimulation increases phosphoinositide breakdown in the guinea pig cochlea. Neurochem. Int. 14, 327-330.

Orsulakova, A., Stockhorst, E. and Schacht, J. (1976) Effect of neomycin on phosphoinositide labeling and calcium binding in guinea pig inner ear tissues in vivo and in vitro. $\mathbf{J}$. Neurochem. 26, 285-290.

Romero, G., Luttrell, L., Rogol, A., Zeller, K., Hewlett, E. and Larner, J. (1988) Phosphatidylinositol-glycan anchors of membrane proteins, potential precursors of insulin mediators. Science $240,509-511$.

Schacht, J. and Zenner. H.P. (1987) Evidence that phosphoinositides mediate motility in cochlear outer hair cells. Hear. Res. 31, 155-159.

Standaert, M.L. and Pollet, R.J. (1988) Insulin- glycerolipid mediators and gene expression. FASEB J. 2, 2453-2461.

Stockhorst, E. and Schacht, J. (1977) Radioactive labeling of phospholipids and proteins by cochlear perfusion in the guinea pig and the effects of neomycin. Acta Otolaryngol. 83, 401-409.

Tachibana, M., Anniko, M. and Schacht, J. (1983) Effects of perilymphatically perfused gentamicin on microphonic potential, lipid labeling and morphology of cochlear tissues. Acta Otolaryngol. 96, 31-38.

Thalmann, R. (1971) Metabolic features of auditory and vestibular systems. Laryngoscope 81, 1245-1260.

Walker, P.S., Donovan, J., Ness, B.G.V., Fellows, R.E. and Pessin, J.E. (1988) Glucose-dependent regulation of glucose transport activity, protein and mRNA in primary cultures of rat brain glial cells. J. Biol. Chem. 263, 15594-15601.

Widdas, W.F. (1988) Old and new concepts of the membrane transport for glucose in cells. Biochim. Biophys. Acta 947, $385-404$. 